\title{
Tumor Necrosis Factor Receptor Superfamily Member 3
}

National Cancer Institute

\section{Source}

National Cancer Institute. Tumor Necrosis Factor Receptor Superfamily Member 3. NCI

Thesaurus. Code C116042.

Tumor necrosis factor receptor superfamily member 3 (435 aa, $\sim 47 \mathrm{kDa}$ ) is encoded by the human LTBR gene. This protein plays a role in both receptor signaling and the positive regulation of apoptosis. 